Pak. j. sci. ind. res. Ser. B: biol. sci. 201255 (1) 30-34

\title{
Spices Mix Induces Biofilm Mode of Growth in Escherichia coli
}

\author{
Zulfiqar Ali Mirania*, Muhammad Naseem Khana, Mubashir Aziz \\ Lakht-E-Zehra ${ }^{a}$, Korish Hasnain Sahir ${ }^{a}$ and Seema Ismat Khan ${ }^{a}$ \\ ${ }^{a}$ Food \& Marine Resources Research Center, PCSIR Laboratories Complex, Karachi-75280, Pakistan \\ ${ }^{b}$ Department of Microbiology, University of Karachi, Karachi-75270, Pakistan
}

(received April 15, 2011; revised December 16, 2011; accepted December 23, 2011)

\begin{abstract}
The present study describes the effect of composite spices mix on E. coli. This strain (E. coli) exhibited high level of resistance to spices and was able to grow in the presence of $500 \mu \mathrm{g} / \mathrm{mL}$ of spices mix as supplement in Brain Heart Infusion (BHI) Broth. In vitro studies showed that spices mix induces biofilm mode of growth which help bacteria to annul the toxic effects and modify it to grow under stress conditions. Electron Micrographs indicates heterogeneity in biofilms structure, where majority of the cells showed the production of extra cellular matrix material and other just adhere around the multi-cellular aggregate of biofilms without producing extra cellular matrix material under spices stress environment. It is concluded that sub-lethal concentration of spices could be harmful for human health by inducing biofilms mode of growth of food born pathogens.
\end{abstract}

Keywords: E. coli, biofilm, antimicrobial activity, spices

\section{Introduction}

Spices are used as major food additives to enhance the taste and aroma of various dishes in the sub-continent. They also give variety, diversity, and wide range of recipes to the Asian cuisine. In particular, salt and red chillies are used almost in every food item to make it tastier especially in South-Asian nations like India, Pakistan, Sri Lanka and Bangladesh. These traditional spices not only enhance the deliciousness but, are also used to inhibit bacterial and fungal growth and enhance the shelf life of food (Saeed et al., 2006). Studies in the past decade confirmed that the growth of both grampositive and gram-negative food borne bacteria, yeast and mold can be inhibited by garlic, onion, cinnamon, cloves, thyme, sage, and other spices (Shelef, 1983). Effects of the presence of these spices can be seen in food products such as pickles, bread, rice, and meat products (Snyder, 1997). However, the fat, protein, water, and salt contents of food also reported to influence anti bacterial activity of these natural herbal compounds (Snyder, 1997). Thus, it is observed that some time high dosages of spices are necessary to inhibit the growth of unwanted bacteria in food (Verluyten et al., 2004; Snyder, 1997). Moreover, antimicrobial effectiveness of spices also depends on the kind of spice, its composition and concentration, type and concentrations of the target microorganism, substrate composition, and processing and food storage conditions (Rahman et al.,

*Author for correspondence; E-mail: mirani_mrsa@yahoo.com
2011). Bacteria, in response, also employ different strategies to abolish the toxic effects of the preservatives or additives present in the food items, which are full of nutrients (Savadogo et al., 2006). Biofilm mode of growth is one of the strategies employed by both pathogenic and non-pathogenic bacteria to survive under various stress induced environments. In the present study biofilm producing isolate of $E$. coli, isolated from composite spices mix sample has been described.

\section{Materials and Methods}

Pure cultures of isolates were preserved at $4{ }^{\circ} \mathrm{C}$ on nutrient agar slants. In order to confirm the identity of the test bacterial isolates, morphological characteristics and conventional biochemical tests were performed as described previously (Harley and Prescott, 2002).

Sensitivity of $E$. coli to spices by agar diffusion method. Antimicrobial activity of spices was tested by agar diffusion method. The plates containing Mueller-Hinton agar were spread with either $0.1 \mathrm{~mL}$ of the $E$. coli inoculum. Wells (8 $\mathrm{mm}$ in diameter) were cut from agar plates using a sterilized stainless steel borer and were filled with $1 \%$ to $5 \% \mathrm{~mL}$ of spices and incubated at $35^{\circ} \mathrm{C}$ for $24 \mathrm{~h}$. Any resultant zone of inhibition was measured and was repeated three times. Spices concentration showing a clear zone of more than $12 \mathrm{~mm}$ was considered to be effective.

Sensitivity of $\boldsymbol{E}$. coli to spices by agar dilution method. Stock solution was made by adding $20 \mathrm{~g}$ of the spices 
mixing $100 \mathrm{~mL}(\mathrm{~W} / \mathrm{V})$ of hot sterile water and allowed to stand for $72 \mathrm{~h}$. Then different concentrations ranging from $4 \mu \mathrm{g} / \mathrm{mL}$ to $1000 \mu \mathrm{g} / \mathrm{mL}$ from this stock solution was added to Mueller-Hinton broth and inoculated with over night culture of subject strain $E$. coli and incubated at $35^{\circ} \mathrm{C}$ for $48 \mathrm{~h}$.

Biofilm assay. A qualitative assessment of biofilm formation by $\mathrm{CP} 2$ on glass slides was evaluated. Two inch pieces each of glass slide was submerged in MullerHinton broth supplemented with different concentrations of spices ranging from $4 \mu \mathrm{g} / \mathrm{mL}$ to $1000 \mu \mathrm{g} / \mathrm{mL}$ separately, inoculated with $0.1 \mathrm{~mL}$ of $4 \mathrm{~h}$ young culture of subject strain of $E$. coli and incubated at $35{ }^{\circ} \mathrm{C}$ for $24-72 \mathrm{~h}$. After incubation, glass slides were removed from broth and washed with phosphate buffer saline $(\mathrm{pH} 7.0)$ to remove unbound cells and debris; biofilms were fixed with acetic acid for $15 \mathrm{~min}$, stained with 3\% crystal violet (Mirani and Jamil, 2011). Each experiment was repeated four times.

Quantification of biofilm. Biofilm formation was quantified by the addition of $2 \times 200 \mu \mathrm{L}$ of $95 \%$ ethanol as described by O'Toole et al. (2000) and absorbance was recorded with Spectrophotometer (Nicollet Evolution $300 \mathrm{BB}$ ) at $563 \mathrm{~nm}$ wave length.

Transmission electron microscopy. Glass slides showing the adhered cells were divided into $4 \mathrm{~mm}$ pieces and rinsed with de-ionized distilled water and negatively stained by $2 \%$ Uranyl Acetate for $2 \mathrm{sec}$. and observed under electron microscope (JEOL-JEM-1200EX1I). Each experiment was repeated four times.

\section{Results and Discussion}

This strain isolated from spices mix was identified as E. coli according to biochemical and morphological characteristics. This E. coli isolate exhibited high level of anti-spices resistance and found to grow in the presence of $>500 \mu \mathrm{g} / \mathrm{mL}$ spices.

Biofilm formation. It was noticed that after exposure to $>200 \mu \mathrm{g} / \mathrm{mL}$ spices this isolate of $E$. coli adopted biofilm mode of growth (Fig. 1-2) and with increasing concentration of spices the thickness of biofilm increased and highest quantity of biofilm forming cells were observed in the presence $500 \mu \mathrm{g} / \mathrm{mL}$ spices after $72 \mathrm{~h}$ of incubation at $35^{\circ} \mathrm{C}$. Electron Micrographs indicates that biofilms producing cells have rough surface as compared to control biofilm negative isolates. In biofilm matrix cells were arranged in bunches and attached to each other and the extracellular biofilm matrix was found trapping the particles of spices used to induce the biofilm mode of growth by subject isolate of $E$. coli. Heterogeneity, in biofilm formation was noticed as all the cells were not found to produce extracellular matrix material required for biofilm formation. It was also noticed that some cells were embedded into the extracellular matrix material and some cells were attached on outer side of the matrix material.

Bacteria encountered in food processing environment can be very difficult to eliminate due to their adaptability under stress conditions. Food borne pathogens are known to adopt biofilm mode of growth under stress environments. Biofilm mode of growth involves attachment of matrix-enclosed bacterial populations to solid surface and interaction between bacterial cells, and surrounding environment (Hall-Stoodley et al., 2004). Generally, biofilms are resistant to anti-bacterial agents (Stewart and Costerton, 2010). In food hygiene, biofilms are also very important potential hazard and a source of bacterial contamination of foods (Furukawa et al., 2010). E. coli is considered as one of the major food borne pathogens and has been known to produce exopolysaccharides which can provide a physical barrier to protect cell from environmental stress (Ryu and Beuchat, 2005). Exopolysaccharides are also involved in bacterial adhesion and biofilm formation (Ryu and Beuchat, 2005). It was observed that spices mix induces the biofilm mode of growth in E. coli (Fig. 2). Naturally, spices are being used as anti-bacterial food additives to reduce the bacterial growth and increase the shelf life of food items. In a study, Vattem et al. (2007) described that dietary phytochemicals from plants, target quorumsensing system and inhibit food spoilage and biofilm formation in food-related bacteria. Conversely, the subject isolate of $E$. coli was found to nullify the toxic effect of spices by adopting biofilm mode of growth (Fig. 2). The role of spices in bacterial biofilm formation has not yet been described clearly. Spices mix contains $\mathrm{NaCl}$ along with other compounds e.g. ginger and garlic. Extensive literature has suggested that $\mathrm{NaCl}$ is responsible for induction of biofilm mode of growth in bacteria (Lim et al., 2004; Conlon et al., 2002; Rachid et al., 2000). Salts generate high osmotic pressure which may damage the bacterial cell wall. Mirani and Jamil (2011) described that cell wall deformity and the state of cell wall deficiency encourages the biofilm formation in bacteria and protects it from toxic effect of antibacterial agents. Ginger and garlic are reported to have very strong antimicrobial activity (Khan et al., 2009) and inhibit bacterial biofilms by blocking quorum sensors 
system (Kamal et al., 2010). However, the composite spice mixes, used in Pakistan, do not have the property to kill or inhibit bacteria because very small subinhibitory quantities of various herbs and spices are added to create a delicious mixture. They are mainly added as flavorings and coloring agents.

However, they are also a source of many other substances, such as sugars, nitrates, and metallic ions. Therefore, when bacteria achieved the resistance and nullify the toxic effect of spices it will get an environment with full of necessary elements for their survival. Consequently, sub-inhibitory concentrations of these compounds generate a stress environment which results in induction of biofilm mode of growth which is beneficial for bacterial survival under stressed environments (Fig. 2). It has, therefore, been speculated that the improper use of biocides may have an insidious effect, contributing to the evolution and persistence of pathogens within microbial communities and might lead to the selection of antibacterial resistance. An important component of Pakistani spices mixes is garlic. According to Rasmussen et al. (2005) and Teplitski et al. (2000) garlic extract proved to contain a minimum of three different QS inhibitors, one of which has been identified to be a cyclic disulphur compound. Quorum sensing (QS) renders the biofilm bacteria highly tolerant to otherwise lethal doses of antibiotics, and protects against the bactericidal activity of polymorphonuclear leukocytes (PMNs). Contrary, in present study spices mix was used which contained $\sim 6 \%$ each of ginger and garlic. It was found to induce biofilm formation in subject isolate of $E$. coli. The other important component

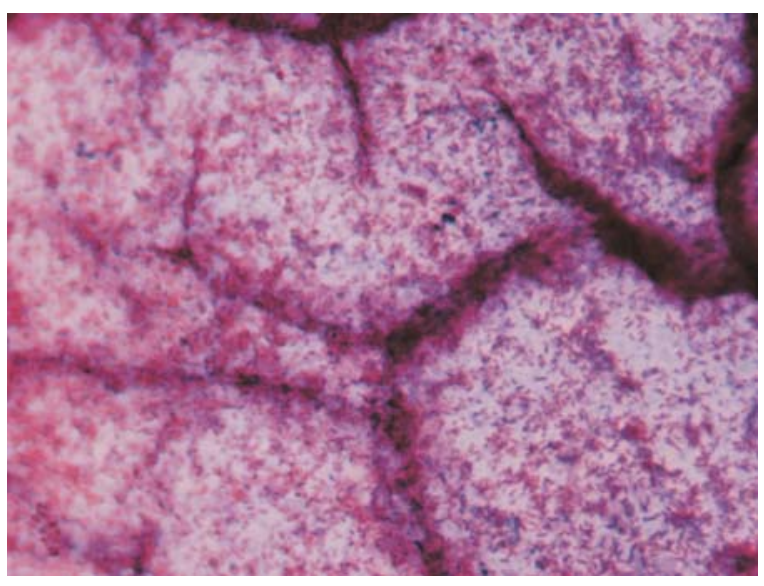

Fig. 1. Micrograph of E. coli cells recovered from biofilm matrix material. of local spices mix is black pepper $(\sim 5 \%)$, which is very active against both gram positive and gram negative bacteria. Karsha and Lakshmi (2010) reported the minimum inhibitory concentration ranged between 62.5 to $125 \mathrm{ppm}$ for gram positive bacteria and 125 to $250 \mathrm{ppm}$ for gram negative bacteria. They described that pepper alters the membrane permeability resulting in the leakage of the UV260 and UV280 absorbing material. Leakage of intracellular materials might cause cell death, which seems to be one of the modes of bactericidal action. Moreover, in biofilm consortia two types of populations were noticed: one embedded in extracellular matrix material (Fig. 2A) and the other attached on the extremer surface of matrix material (Fig. 2B). It seems that in the single population of subject isolate of $E$. coli two types of cells exist; some cells produce biofilm material around itself to avoid

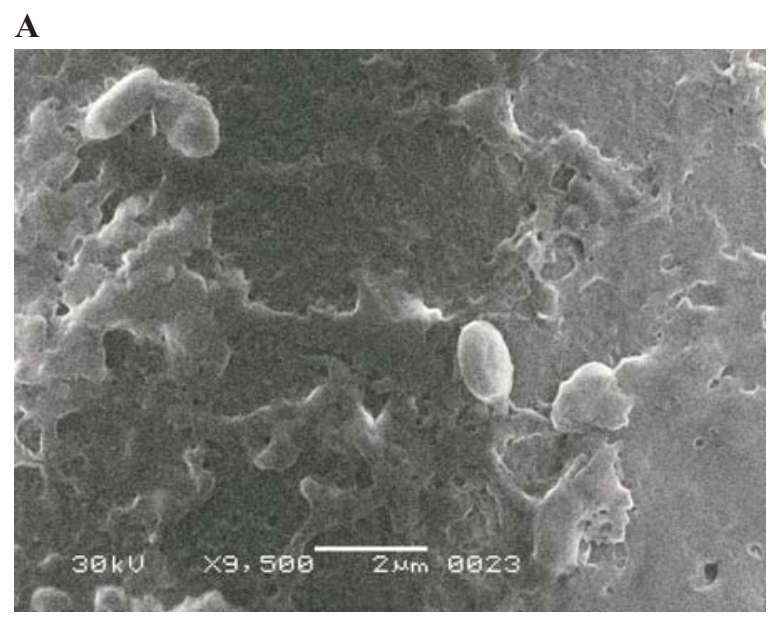

B

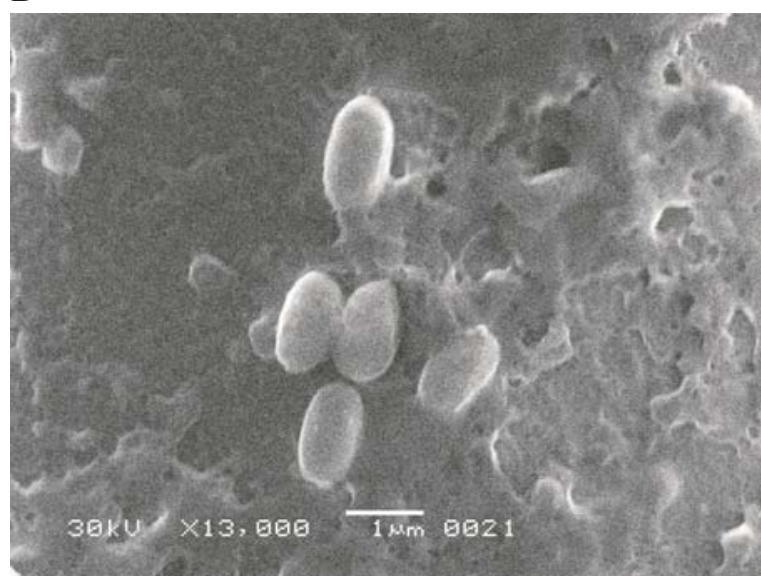

Fig. 2. Electron micrographs of E. coli cells exhibited rough surfaces (A) and attached on the surface of biofilm matrix material (B). 
the toxic effect of spices (Fig. 2A) and also attract and trap the biofilm non producers to the biofilm consortia. Vlamakis et al. (2008) described that biofilms harbor multiple cell types. It has also been proposed that within biofilms individual cells follow different developmental pathways, resulting in heterogeneous populations. The composite spices mix used in present study composed of different components that have diverse mode of action. Possibly, these compounds may have generated different stress levels in which some cells have adopted biofilm mode of growth and others have utilized that without changing their living nature. Interestingly, all these compounds have not shown any synergistic effect against subject isolate of $E$. coli. It seems that these compounds antagonized the antibacterial effect of each other which allow the bacteria to survive and multiply. Therefore, it is necessary to study the combined effect of these compounds and makeup the mixture of only those components which have synergistic effect and not only provide good taste but also inhibit the bacteria, otherwise as noticed in the present study they could be antagonistic to each other, consequently, promote the bacterial growth and become hazardous to human health. Moreover, the present study showed the disadvantages of low dosage of anti-bacterial agents. Under normal circumstances, ginger and garlic are considered as good antibacterial agents, however, when they are used below the bactericidal or bacteriostatic level may create an environment which could be advantageous for bacterial survival. In the case of subject isolate of $E$. coli it was noticed that spices mix which contains very low concentrations of $\mathrm{NaCl}$, chilli, black peppers, ginger and garlic etc. induces biofilm mode of growth and provide stress environment to the bacteria, which is advantageous for bacterial growth and survival.

\section{References}

Conlon, K.M., Humphreys, H., O'Gara, J.P. 2002. icaR encodes a transcriptional epressor involved in environmental regulation of ica operon expression and biofilm formation in Staphylococcus epidermidis. Journal of Bacteriology, 184: 4400-4408.

Furukawa, S., Akiyoshi, Y., O’Toole, G.A., Ogihara, H., Morinaga, Y. 2010. Sugar fatty acid esters inhibit biofilm formation by food-borne pathogenic bacteria. International Journal of Food Microbiology, 138: 176-180.

Hall-Stoodley, L., Costerton, J.W., Stoodley, P. 2004. Bacterial biofilms: from the natural environment to infectious diseases. Nature Review of Micro- biology, 2: 95-108.

Harley, J.P., Prescott, L.M. 2002. Laboratory Exercises in Microbiology. $5^{\text {th }}$ edition, pp. 117-121, McGrawHill Publishers, New Youk, USA.

Kamal, S.M., Ravi, A.V., Annapoorani, A., Packiavathy, I.S.V., Pandian, S.K. 2010. Evaluation of antiquorum-sensing activity of edible plants and fruits through inhibition of the $\mathrm{N}$-acyl-homoserine Lactone System in Chromobacterium violaceum and Pseudomonas aeruginosa. Chemotherapy, 56: 333-339.

Karsha, P.V., Lakshmi, O.B. 2010. Antibacterial activity of black pepper (Piper nigrum Linn.) with special reference to its mode of action on bacteria. Indian Journal of Natural Products and Resources, 1: 213-215.

Khan, S.J., Fatima, A., Zaidi, N., Ejaz., N. 2009. Effect of different stabilizers on the antibacterial activity of "ginger garlic paste. Journal of Applied Science and Environment Management, 13: 105-109.

Lim, Y., Jana, M., Luong, T.T., Lee, C.Y. 2004. Control of glucose- and $\mathrm{NaCl}$-induced biofilm formation by rbf in Staphylococcus aureus. Journal of Bacteriology, 186: 722-729.

Mirani, Z.A., Jamil, N. 2011. Effect of sub-lethal doses of vancomycin and oxacillin on biofilm formation by vancomycin intermediate resistant Staphylococcus aureus. Journal of Basic Microbiology, 51: 191-195.

O'Toole, G.A., Gibbs, K.A., Hager, P.W., Phibbs, P. V.Jr., Kolter, R. 2000. The global carbon metabolism regulator $\mathrm{Crc}$ is a component of a signal transduction pathway required for biofilm development by Pseudomonas aeruginosa. Journal of Bacteriology, 182: 425-431.

Rachid, S., Ohlsen, K., Wallner, U., Hacker, J., Hecker, M., Ziebuhr, W. 2000. Alternative transcription factor $\sigma \mathrm{B}$ is involved in regulation of biofilm expression in a Staphylococcus aureus mucosal isolate. Journal of Bacteriology, 182: 6824-6826.

Rahman, S., Parvez, A.K., Islam, P., Khan, M.H. 2011. Antibacterial activity of natural spices on multiple drug resistant Escherichia coli isolated from drinking water. Bangladesh. Annals of Clinical Microbiology and Antimicrobials, 10: 2-4.

Rasmussen, T.B., Bjarnsholt, T., Skindersoe, M.E., Hentzer, M., Kristoffersen, P., Kote, M., Nielsen, J., Eberl, L., Givskov, M. 2005. Screening for quorumsensing inhibitors (QSI) by use of a novel genetic system, the QSI selector. Journal of Bacteriology, 
187: 1799-1814.

Ryu, J.H., Beuchat, L.R. 2005. Biofilm formation by Escherichia coli O157:H7 on stainless steel: effect of exopolysaccharide and curli production on its resistance to chlorine. Applied Environmental Microbiology, 71: 247-254.

Saeed, S., Naim, A., Tariq, P. 2006. In vitro antibacterial activity of peppermint. Pakistan Journal of Botany, 38: $869-872$.

Savadogo, A., Ouattara, C.A.T., Bassole, I.H.N., Traore, S.A. 2006. Bacteriocins and lactic acid bacteria. African Journal of Biotechnology, 5: 678-683.

Shelef, L.A. 1983. Antimicrobial effects of spices. Journal of Food Safety, 6: 29-44.

Snyder, O.P. 1997. Antimicrobial effect of spices and herbs. www.hitm.com/Documents/Spices.html.

Stewart, P.S., Costerton, J.W. 2010. Antibiotic resistance of bacteria in biofilms. Lancet, 358: 135-138.
Teplitski, M., Robinson, J.B., Bauer, W.D. 2000. Plants secrete substances that mimic bacterial $\mathrm{N}$-acyl homoserine lactone signal activities and affect population density-dependent behaviors in associated bacteria. Molecular Plant Microbial Interaction, 13: 637-648.

Vattem, D.A., Mihalik, K., Crixell, S.H., McLean, R.J.C. 2007. Dietary phytochemicals as quorum sensing inhibitors. Fitoterapia, 78: 302-310.

Verluyten, J., Leroy, F., De Vuyst, L. 2004. Effects of different spices used in production of fermented sausage on growth of curavacin A production by Lactobacillus curvatus LTH 1174. Applied Environmental Microbiology, 70: 4807-4813.

Vlamakis, H., Aguilar, C., Losick, R., Kolter, R. 2008. Control of cell fate by the formation of an architecturally complex bacterial community, Genes \& Development, 22: 945-953. 